\title{
$\mathrm{Al}$ 도금 HPF 강판과 전기아연도금 TRIP 강판의 저항 점 용접 시 연속타점 전극의 수명에 미치는 도금층의 영향
}

\author{
손종우· 서종덕 ${ }^{1} \cdot$ 김동철 $^{2} \cdot$ 박영도 $^{3, \dagger}$ \\ 한창엔지니어링, ${ }^{1}$ 주식회사 신영, ${ }^{2}$ 한국생산기술연구원 용접 접합연구부 \\ 동의대학교 공과대학 신소재공학과 \\ (2012년 2월 9일 접수, 2012년 2월 24일 수정, 2012년 2월 24일 채택)
}

\section{Effect of Coating Layer on Electrode Life for Resistance Spot Welding of Al-Coated Hpf and Zn-Coated Trip Steels}

\author{
Jong Woo Son, Jong-Dock Seo ${ }^{1}$, Dong Cheol Kim ${ }^{2}$, and Yeong-Do Park ${ }^{3,+}$ \\ HANCHANG ENG. CO., LTD. , 782-31, Gomo-Ro, Hanlim-Myeon, Gimhae City, GyeongNam, Korea , Korea \\ ${ }^{1}$ SHIN YOUNG CO.,LTD. , 440 Bonchon-dong, Yeongcheon-si, Gyeongbuk 770-150, Korea \\ ${ }^{2}$ Advanced Welding \& Joining R\&D Division, Korea Institute of Industrial Technology, Incheon 406-840, Korea \\ ${ }^{3}$ Dept. of Advanced Material Engineering, Dong-eui University, Busan 614-714, Korea \\ (Received February 9, 2012; Revised February 24, 2012; Accepted February 24, 2012)
}

\begin{abstract}
The resistance spot welding of high strength steel degrades the weldability because of its high strength with rich chemical composition and coating layer to protect from corrosion. During the each resistance welding process the electrodes tip reacts with coating layer, then subsequently deteriorates and shorten electrode life. In this study, the Al-coated HPF (Hot Press Forming) steels and Zn-coated TRIP steels were used to investigate the electrode life for resistance spot welding. Experimental results show that the reactivity of Al-coating on HPF steels to electrode tip surface behaviors different from the conventional Zn-coated high strength steels. The electrode tip diameter and nugget size in electrode life test of Al-coated HPF steels are observed to be constant with respect to weld numbers. For Al-coated HPF steels, the hard aluminum oxide layer being formed during high temperature heat treatment process reduces reactivity with copper electrode during the resistance welding process. Eventually, the electrode life in resistance spot welding of Al-coated HPF steels has the advantage over the galvanized steel sheets.
\end{abstract}

Keywords : spot weld, electrode life, high strength steel, hot press forming steel, coating layer

\section{1. 서 론}

최근 철강 재료의 내식성 향상을 목적으로 표면처리 강판 이 다양한 용도로 폭넓게 사용되고 있고 그 중에서도 아연도 금 표면처리 강판의 적용이 현저하게 증가하고 있다. 특히, 북미 및 북유럽에서는 자동차 차체 부식 문제에 기인한 여러 문제점을 해결하기 위하여 자동차 차체의 방청 강화가 요구 되어 왔으며, 차체방청강화를 위해서 표면에 아연 또는 알루 미늄 등을 이용하여 표면처리 한 다양한 도금강판이 개발되 어 왔다.

한편, 자동차 차체 조립 공정에서는 비교적 작업성이 간편 하고 접합강도가 우수한 저항 점용접 공정이 적용되고 있다. 이러한 저항 점용접에서는 용접전류, 용접시간 및 가압력의

\footnotetext{
† Corresponding author: ypark@deu.ac.kr
}

변화에 따라 저항 점용접부의 특성이 크게 좌우된다. 또한 차체 내식성 및 도장성 향상을 위해 사용되는 다양한 표면처 리강판은 저항 점용접에서 연속적인 용접공정을 거치면서 표면 도금층과 전극과의 반응이 지속적으로 발생하며, 도금 층의 용융 및 픽업에 따른 전극의 합금화 현상이 문제점으로 보고되어 왔다. ${ }^{1) ~ 5)}$ 이러한 전극 합금화 현상은 용접 전극의 수명을 단축시켜, 차체 조립라인의 생산성 저하를 가져오는 것으로 알려져 있다. 따라서 자동차 차체에 적용되는 도금강 판의 경우 저항 점용접 연속타점 수명 평가를 통한 전극의 수명에 대한 평가가 반드시 수행 되어야 한다.

최근 연비 향상을 위한 차체경량화가 요구되어 고강도 강 판의 적용이 많이 요구됨에 따라 이에 대한 저항 점용접 특 성에 대한 연구 또한 큰 진보를 이루어 왔다. ${ }^{3) ~ 5)}$ 여러 연구 결과들에서 고강도 강판의 저항 점용접 특성은 연강의 용접 특성과 차이가 있는 것으로 보고되고 있으며 연속타점 수명 
또한 그 강판의 강도에 영향을 받는 것으로 알려져 있다. ${ }^{3) ~ 5)}$ 고강도 강판에서 저항 점용접의 연속타점 특성이 저하되는 이유는 크게 3 가지로 알려져 있다. 첫째 고강도 강판의 높은 강도로 인하여 가압력 조건이 기존의 강판보다 상승하여 전 극의 합금화가 심화되는 것이며, 두 번째로 고강도 강판에 함유된 합금원소로 인해 기존의 냉연강판보다 높은 발열이 발생되며 전극 표면과 도금층 간의 열화가 빠르게 진행되기 때문에 최종적으로 전극의 수명이 단축되는 것이다. 마지막 으로 자동차용 고강도 강판에서 대부분 적용되는 도금층의 성분 및 두께에 따른 특성으로 인하여 전극의 합금화 속도가 증가하게 된다. ${ }^{2) 51}$ 이러한 저항 점용접 특성으로 인해, 새 롭게 개발되는 자동차용 강판들은 기본적으로 연속타점 수 명 평가를 통한 용접성 평가가 필수적이다.

자동차용 강판으로 적용되는 고강도 강판 중 자동차의 연 비 향상 및 충돌 성능 향상을 목적으로 개발된 $\mathrm{HPF}$ (Hot Press Forming) 강판은 고온 성형 공정 중 열처리를 실시 하여 최종 부품의 강도를 극대화 한 강판에 일종이다. 이 공정은 기존의 성형법과는 달리 일반 냉연강판을 모재로 하 여 고온으로 가열하여 고온 성형과 담금질을 유도하는 급냉 의 연속공정으로 이루어지며 이를 통해 약 1000 1600 $\mathrm{MPa}$ 의 고강도를 갖는다. 이러한 $\mathrm{HPF}$ 강판은 고온 성형 시 발생하는 산화를 방지하기 위해 여러 가지 도금재가 적용되 고 있다. $\mathrm{HPF}$ 공정을 적용한 강의 도금 재료 중 대표적으로 사용되고 있는 것이 $\mathrm{Al}-\mathrm{Si}$ 계 이다. $\mathrm{Al}-\mathrm{Si}$ 도금층은 $\mathrm{HPF}$ 공정 시 고온 가열된 소재가 열처리 또는 금형으로 이동할 때 발생하는 공기의 접촉을 억제하여 산화스케일을 방지하 는 역할을 한다. 일반적으로 약 $30 \mu \mathrm{m}$ 정도의 $\mathrm{Al}-\mathrm{Si}$ 코팅 처리를 하고 있으며 열처리 가열 조건에 따라 모재와 반응하 여 $\mathrm{Fe}-\mathrm{Al}-\mathrm{Si}$ 로 이루어진 금속간 화합물 층을 생성 시킨다. 또한 도금층의 최외각에서는 분위기 또는 대기중의 산소와 반응에 따른 약 $5 \mu \mathrm{m}$ 정도의 $\mathrm{Al}$ 산화층이 $\left(\mathrm{Al}_{2} \mathrm{O}_{3}\right)$ 생성되 게 된다. 이러한 $\mathrm{Al}$ 산화층의 존재는 $\mathrm{HPF}$ 강판의 저항 점용 접에서 적정 용접 구간 생성에 불리한 영향을 주게 되는데, 이는 저항 점용접의 너깃 생성이 모재의 접촉 저항에 따라 변화하기 때문으로 알려져 있다. ${ }^{6) ~ 7) ~}$

따라서 본 연구에서는 $\mathrm{Al}-\mathrm{Si}$ 이 코팅된 $\mathrm{HPF}$ 강판의 저항 점용접 특성 중 연속적인 저항 점용접 시 전극의 연속타점 수명 평가를 실시하였다. 전극 수명 평가의 경우 강판 표면 도금층이 가장 큰 변수로 작용하기 때문에 비교 분석을 위하 여 전기아연도금 된 TRIP 강판의 저항 점용접 연속타점 수 명 평가 결과와 비교하였다. 각각의 강판에서 연속적인 저항 점용접 시 변화되는 전극 선단경의 성장 및 전단인장강도의 변화를 분석하고, 저항 점용접 연속타점 시 도금층 물성차이 에 따른 전극과 전극표면의 합금화 거동을 관찰하였다.

\section{2. 연구방법}

\section{1 실험재료 및 용접조건}

본 실험에 사용된 재료는 $\mathrm{Zn}$ 가 도금된 $1.4 \mathrm{~mm}$ 두께의 $590 \mathrm{MPa}$ 급 $\mathrm{TRIP}$ 강판 $(\mathrm{C}=0.098 \%)$ 과 $\mathrm{Al}$ 이 도금된 1.6 $\mathrm{mm}$ 두께의 $1.5 \mathrm{GPa}$ 급 $\mathrm{HPF}$ 강판 $(\mathrm{C}=0.23 \%)$ 이다. TRIP 강판은 오스테나이트와 베이나이트 안정화 원소인 $\mathrm{Mn}$ $(1.5 \%)$ 과 $\mathrm{Si}(0.981 \%)$ 을 첨가하여 열처리 후의 조직이 잔 류오스테나이트, 베이나이트, 펼라이트로 구성되어 있어 우 수한 성형성과 가공 후 고강도를 유지하는 특징이 있다. 본 실험에서 사용된 TRIP 강판은 전기아연도금 처리를 하여 용융아연도금 처리된 강판과 비교 하였을 때 도금층의 두께 가 얇고 평활한 도금층을 가지게 되며, 상온에 가까운 온도 영역에서 도금 공정이 이루어져 원판(고강도 강판)의 재질 을 변화 시키지 않는 특징이 있다. 각각의 시편 도금층 두께 를 분석하기 위해 판재 단면을 SEM(Scanning Electron Microscope)을 이용하여 관찰하였으며 이를 그림 1에 나 타내었다. 그림 1(a)는 전기아연 도금 처리한 TRIP 강판의 $\mathrm{SEM}$ 관찰 결과이며 약 $4 \mu \mathrm{m}$ 의 도금층이 관찰되었다. 그림
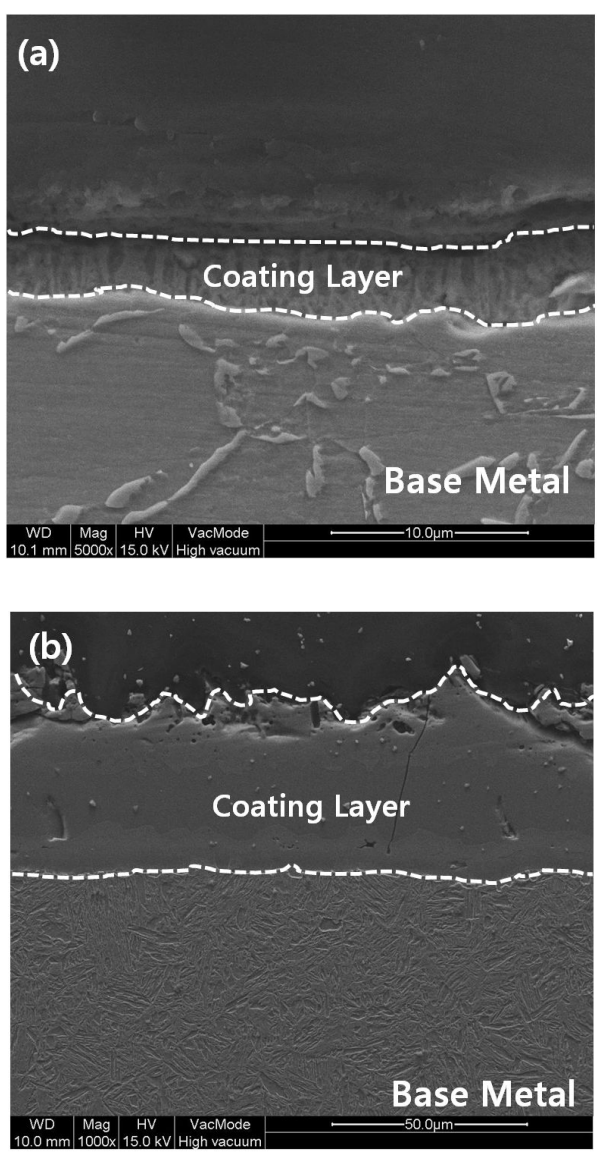

Fig. 1. SEM images of cross section of (a) $\mathrm{Zn}$ coated TRIP Steel (5000x) (b) Al coated HPF Steel (1000x) including coating layer. 
Table 1. Welding parameters used for electrode life test

\begin{tabular}{|c|c|c|c|c|c|c|c|c|c|}
\hline \multirow{2}{*}{$\begin{array}{c}\text { Sheet } \\
\text { Thickness }(\mathrm{mm})\end{array}$} & \multicolumn{3}{|c|}{ Electrode } & \multirow{2}{*}{$\begin{array}{l}\text { Weld Time } \\
\text { (cycle) }\end{array}$} & \multirow{2}{*}{\multicolumn{2}{|c|}{$\begin{array}{l}\text { Hold Time } \\
\text { (cycle) }\end{array}$}} & \multirow{2}{*}{\multicolumn{2}{|c|}{$\begin{array}{l}\text { Welding Rate } \\
\text { (w/min.) }\end{array}$}} & \multirow{2}{*}{$\begin{array}{c}\text { Welding } \\
\text { current }(\mathrm{kA})\end{array}$} \\
\hline & $\begin{array}{l}\text { Distance } \\
(\mathrm{mm})\end{array}$ & $\begin{array}{c}\text { Force } \\
(\mathrm{kN})\end{array}$ & $\begin{array}{l}\text { Cooling } \\
\text { (L/min.) }\end{array}$ & & & & & & \\
\hline $\mathrm{Zn}$ coated TRIP & 7.0 & 3.8 & 6.0 & 16 & \multicolumn{2}{|l|}{10} & \multicolumn{2}{|c|}{15} & 7.0 \\
\hline \multirow{2}{*}{$\begin{array}{c}\text { Sheet } \\
\text { Thickness }(\mathrm{mm})\end{array}$} & \multicolumn{3}{|c|}{ Electrode } & \multicolumn{4}{|c|}{ Weld Time (cycle) } & \multirow{2}{*}{$\begin{array}{l}\text { Hold Time } \\
\text { (cycle) }\end{array}$} & \multirow{2}{*}{$\begin{array}{c}\text { Welding } \\
\text { Rate } \\
\text { (w/min.) }\end{array}$} \\
\hline & $\begin{array}{l}\text { Distance } \\
(\mathrm{mm})\end{array}$ & $\begin{array}{c}\text { Force } \\
(\mathrm{kN})\end{array}$ & $\begin{array}{l}\text { Cooling } \\
\text { (L/min.) }\end{array}$ & $\begin{array}{c}\text { Number of } \\
\text { Pulses }\end{array}$ & $\begin{array}{c}\text { Weld Time } \\
\text { (cycle) }\end{array}$ & $\begin{array}{r}\text { Hold } \\
\text { (cy }\end{array}$ & $\begin{array}{l}\text { Time } \\
\text { cle) }\end{array}$ & & \\
\hline Al coated HPF & 8.0 & 4.5 & 6.0 & 3 & 11 & 2 & 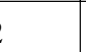 & 20 & 15 \\
\hline
\end{tabular}

1 (b)는 $\mathrm{Al}$ 이 도금된 $\mathrm{HPF}$ 강판의 $\mathrm{SEM}$ 관찰 결과이며 약 $40 \mu \mathrm{m}$ 의 도금층이 관찰되었다.

실험에 사용된 용접기는 단상 $\mathrm{AC}$ 용접기를 사용하였으며 용접기의 냉각수는 약 $8 \ell / \mathrm{min}$ 으로 일정하게 공급되었다. 실험에 적용된 고강도 강판의 두께에서 $0.2 \mathrm{~mm}$ 차이가 발 생해 AWS 용접 규격에 따라 용접 조건이 다르게 실험을 진행하였다. 저항 용접에 적용된 전극은 TRIP 강판이 7 $\mathrm{mm}, \mathrm{HPF}$ 강판이 $8 \mathrm{~mm}$ 인 $\mathrm{Cu}-\mathrm{Cr}$ 재를 적용하였으며 실험 전 용접에 사용될 판재 시편은 표면의 윤활유 및 불순물을 제거하기 위해 에틸 알코올로 세척하였다. 연속타점 수명 평가를 위한 기준은 AWS D 8.9규격을 적용하여 연속타점 수명 평가를 실시하였으며, 표 1 에 각각의 강판에 따른 저항 점용접 연속타점 수명평가를 위한 용접 조건을 나타내었다.

\section{2 연속타점 수명 평가 방법}

연속타점 수명평가 기준은 $\mathrm{AWS}$ 저항 점용접 전극 수명 평가를 기준으로 하였으며, 기계적인 시험의 용접 시편은 ISO 용접 시험 기준을 적용하여 실험을 진행하였다. 연속타 점 수명 평가 시 저항 점용접부 버튼 사이즈가 $4.5 \sqrt{\mathrm{t}}$ 이하가 될 때 연속타점을 종료하였다. 그리고 연속적인 저항 점용접 으로 합금화가 진행되는 전극의 직경변화를 관찰하기 위하 여 0타점부터 200타점 간격으로 Carbon paper를 이용하 여 전극의 마모에 따른 직경변화를 측정하였다. 연속타점 실험 종료 후 전극의 합금화 현상 분석을 위해 전극 표면부 를 SEM 과 EDS(Energy Dispersive Spectroscopy)를 이용하여 분석을 실시하였다.

연속타점 실험이 종료된 시편의 표면은 모재의 영향으로 합금화가 일어나게 되며 모재강판의 도금층이 전극 표면에 묻어나게 되는데 이러한 연속타점에 의한 전극의 합금화 깊 이 측정을 위하여 연속타점이 끝난 시편의 단면에 대해 표면 에서부터 $1 \mu \mathrm{m}$ 간격으로 합금성분 분석을 실시하여 도금 층 성분의 침투 깊이를 조사하였으며, 모재 도금층 및 용접 조건에 따라 달라지는 전극의 합금화를 분석하였다.

\section{3. 연구결과 및 고찰}

\section{1 저항 점용접 연속타점 시 전단인장강도 변화}

일반적인 연강의 저항 점용접 연속타점 평가의 경우 연속 타점수의 증가에 따라 용접부 전단인장강도가 감소한 다. ${ }^{2)}$ 5) 그러나 표면 도금처리 ( $\mathrm{Zn}$ 또는 $\mathrm{Al}$ 도금) 가 된 고강 도 강판의 경우, 특히 $\mathrm{Al}-\mathrm{Si}$ 계 코팅이 적용된 $\mathrm{HPF}$ 강의 경 우 표면 도금층의 물성이 일반 $\mathrm{Zn}$ 도금과는 차이가 존재하 므로 저항 점용접 연속타점 수명에도 변화가 예상된다.

그림 2(a)는 전기아연도금 처리된 TRIP강판의 연속타점 수명평가 과정에서 200 타점 간격으로 전단인장강도를 측 정한 결과이다. 약 3000 타점 이전까지 일정한 최대 전단인 장강도를 유지하였으나 3200 타점에서 계면파단이 발생하 였고 이때 전단인장강도가 약 $10 \mathrm{kN}$ 하락하였다. 3200 타 점 이전의 전단인장강도가 일정하게 유지되는 이유는 연속 타점수명 평가 시 초기 용접 전류조건이 날림 발생 직하의 조건이며 이때 최대 너깃경을 확보할 수 있기 때문이다. 연 속타점 평가가 진행되면서 전극의 합금화 현상 및 마모가 발생하게 되고, 이와 동시에 전극의 합금층이 성장과 소실을 반복하게 된다. ${ }^{8) ~ 10)}$ 최종적으로 연속타점 용접 진행과 함께 전극 직경이 성장하며 전류 밀도 또한 감소하게 되는데, 그 림 2(a)의 TRIP 강판에서 관찰되는 전단인장강도의 급격 한 감소가 이러한 전극 합금화 및 마모 현상으로 인해 통전 전류밀도가 급격히 감소하여 충분한 용융이 발생하기 때문 에 발생한 현상이다. 따라서 생성된 용융 너깃의 크기가 파 단시험 시 하중을 지탱하지 못하고 용접접합부 경계을 따라 최종적으로 계면파단 (Interfacial Fracture; IF)이 발생하 였다. 3200 타점 이후 관찰되는 전단인장강도의 회복은 합 금층이 성장과 소실을 반복하게 되어 전극 직경이 다시 감소 되면서 통전 전류밀도가 증가되는 현상으로 알려져 있 다. ${ }^{8) ~ 10)}$

그림 2(b)에 $\mathrm{HPF}$ 강판의 저항 점용접 연속타점 타수별 전단인장강도 측정 결과를 나타내었다. 전단인장강도 측정 

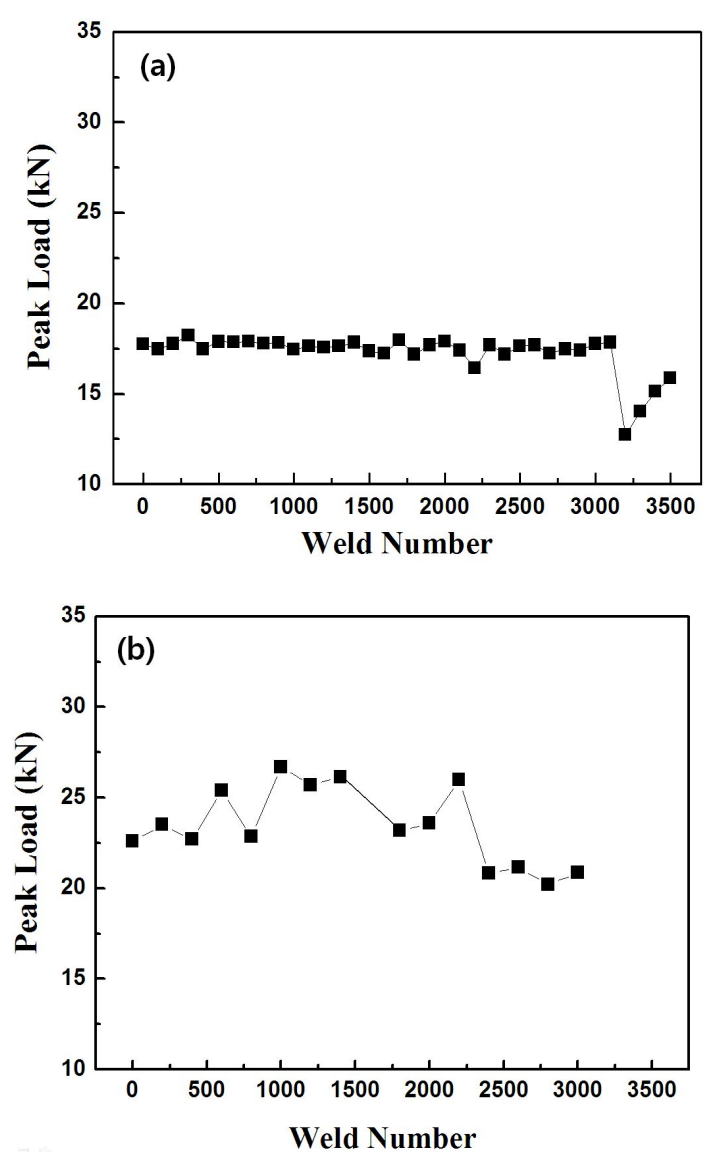

Fig. 2. Comparison of the tensile-shear load as a function of the weld numbers.

결과 3000 타점까지 불규칙적인 변화를 보이며 모든 타점 구간에서 $20 \mathrm{kN}$ 이상의 전단인장강도를 가진다. 전단인장 시험으로 인해 파단 된 시편 관찰 결과 $1800,2000,2400$, 2600 타점에서 계면파단이 발생하였으나 전단인장강도는 감소하지 않은 것으로 관찰되었다. 이러한 불규칙한 전단인 장강도와 저항 점용접부 계면파단은 $1.0 \mathrm{GPa}$ 급 강도 이상 고강도강의 저항 점용접 시 발생하는 특징으로서 충분한 저 항 점 용접부 너깃 사이즈에도 불구하고 전단인장시험 시 용접부 및 열영향부의 취성이 큰 미세조직으로 인하여 계면 파단이 쉽게 발생하기 때문이다. ${ }^{3)} \mathrm{HP} \mathrm{HPF}$ 강판의 경우 TRIP 강판의 전단인장 강도 변화와 같은 강도의 감소는 발 견되지 않았으나, 소재 강도의 영향으로 실험 영역에서 TRIP 강판의 저항 점용접 전단인장 강도보다 높게 측정되 었다. TRIP 강과는 달리 불규칙 적인 강도의 변화는 $\mathrm{HPF}$ 강의 저항 점용접 파단 특성과 관련이 존재할 것으로 사료 된다.

전기아연도금 $\mathrm{TRIP}$ 강판과 $\mathrm{Al}-\mathrm{Si}$ 도금 $\mathrm{HPF}$ 강판 모두 연 속타점 수에 따른 최소 전단인장강도 기준을 만족 하고 있으 나 건전한 저항 점 용접부 연속타점 특성을 고찰하기 위해서
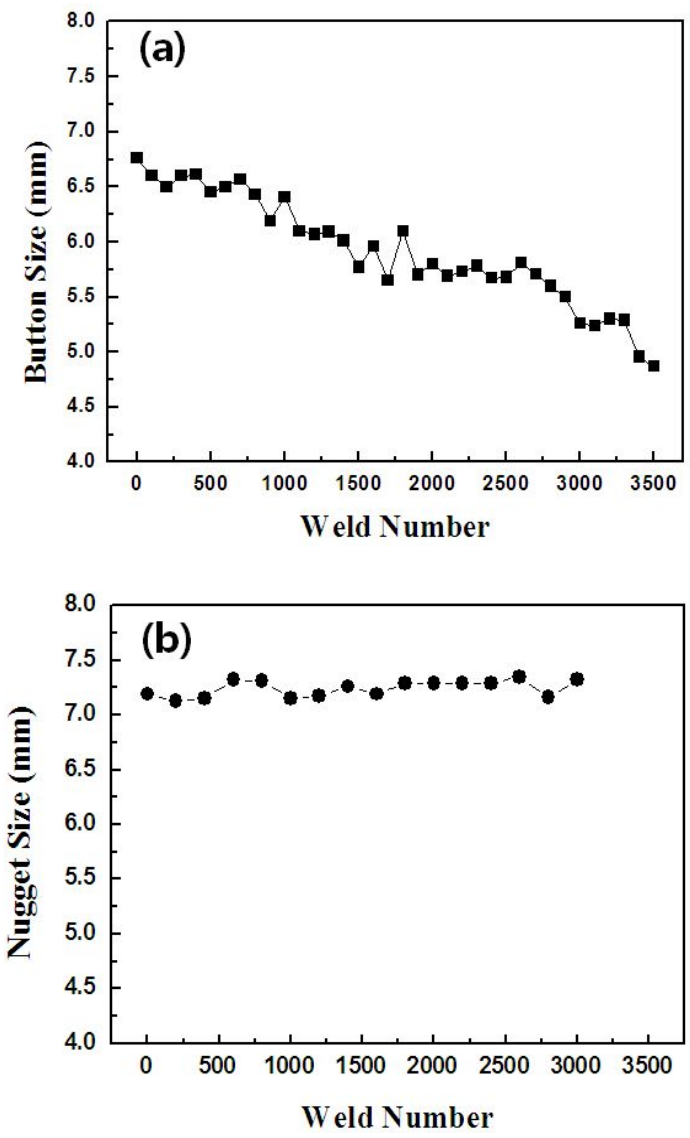

Fig. 3. Comparison of button diameter and nugget diameter as a function of the weld numbers. ; (a) Zn coated TRIP Steel (b) Al coated HPF Steel.

는 전극의 선단경과 버튼및 너깃 직경의 변화와 함께 고찰되 어야 한다.

\section{2 저항 점용접 연속 타점에 따른 버튼직경 및 너깃 직경 변화}

실험에 사용된 두 강판의 연속타점 전극 수명 실험에 따른 저항 점용접 용접성 평가를 위해 0타점부터 200타점 간격 으로 Peel test 시험을 이용한 버튼 사이즈 측정과 용접부 단면 너깃경 측정 시험을 실시하였다. 일반적으로 저항 점 용접 버튼경은 Peel test를 적용하여 측정하나 열처리된 $\mathrm{HPF}$ 강판의 경우 $1.5 \mathrm{GPa}$ 의 높은 강성으로 인해 Peel test 가 용이하지 않아 용접 단면의 너깃 사이즈를 측정하여 저항 점용접 용접부의 용접성을 판단하였다.

도금강판의 연속타점 수명은 강판의 종류 외에도 도금층 의 성분 및 도금법에 따라서 차이를 나타내며 일반적으로 전기 아연도금강판보다 용융아연 도금강판의 연속타점 수 명이 짧은 것으로 알려져 있다. ${ }^{8)}$ 그림 3 은 전기아연도금 TRIP 강판과 $\mathrm{Al}-\mathrm{Si}$ 도금 $\mathrm{HPF}$ 강판의 저항 점용접 연속타 점 수에 따른 버튼 사이즈와 너깃 사이즈를 측정한 결과이 
다. 그림 3(a)는 전기아연도금 TRIP강판의 연속타점 수에 따른 버튼 사이즈 측정 결과로 약 3500 타점까지 지속적인 버튼사이즈의 감소가 관찰되었다. 이러한 버튼사이즈 감소 는 연속적인 저항 점용접 시 전극과 강판표면에서 발생하는 전극의 마모 및 합금화에 기인한 전극 선단경의 성장에 기인 한다. 버튼직경의 변화는 연속적인 용접 시 전극의 중심부에 묻어난 도금 성분에 그대로 용접이 진행되면서 전극 선단부 의 외각으로 도금성분이 밀려나 버섯형태의 합금층을 형성 하며, 생성된 합금층은 용접 시 판재와 전극의 충격으로 인 한 축척과 이탈을 반복하여 전극 직경을 불규칙하게 변화시 킨다. ${ }^{810)}$ 이에 따라 전극과 판재사이의 전류밀도가 저하하 게 되며 최종적으로 판재와 판재 사이의 전류 밀도가 저하 되어 저항 점용접부 너깃 직경을 감소 시킨다. 일반적으로 저항 점용접부 너깃 직경의 감소는 Peel test에서 버튼 직경 의 감소로 나타난다.

그림 3 (b)에 $\mathrm{HPF}$ 강판의 저항 점용접 연속타점 타수별 너깃사이즈 측정결과를 나타내었다. TRIP 강판의 연속타점 수명평가에서 전극의 합금화로 인해 너깃사이즈가 감소하 고 이로 인해 버튼사이즈가 감소하게 되는데, 그림 $3(\mathrm{~b})$ 의 $\mathrm{HPF}$ 강판의 연속타점 수명 평가 결과 3000 타점 이상까지 약 $7.3 \mathrm{~mm}$ 전 후의 일정한 너깃 사이즈가 관찰되었다. 따라 서 저항 점용접 연속타점 수명평가에서 $\mathrm{HPF}$ 강판과 TRIP 강판의 전극 선단경 변화가 서로 다른 형태로 진행 되는 것 으로 판단되며, 이를 고찰하기 위하여 각각의 강판 별 저항 점용접 연속타점 시 전극 선단경 성장과 연속타점 후 전극 표면 및 단면 관찰을 실시하였다.

\section{3 저항 점용접 연속타점 시 TRIP 강판과 HPF 강판의 전극 선단경 변화}

3.2 절에서 저항 점용접의 연속타점 수명 평가 시 전극은 모재 표면의 도금층과 합금화가 진행되며, 저항 점용접의 전극 가압력으로 인해 소실과 축적을 반복하면서 전극의 선 단경 길이가 상승하게 된다고 설명하였다. ${ }^{8) ~ 10)}$ 이러한 전극 선단경의 성장 변화를 파악하기 위하여 Carbon imprint 측 정법을 이용하였다. 그림 4 는 Carbon imprint 측정법을 이 용하여 저항 점용접 연속타점 수에 따른 전극 선단경의 변화 를 나타낸 것이다. 그림 4(a) 와 그림 4(b)에서 연속타점 초기의 전극 선단경 지름에 차이가 발생하는 것은 TRIP강 판과 $\mathrm{HPF}$ 강판의 저항 점용접 수명 평가 기준(표 1)이 달라 용접 전극의 지름이 다르기 때문이다.

전극의 성장은 저항 점용접 연속타점 수에 따라 초반에 급격한 성장이 나타나는 Primary 구간과 이후에 성장속도 가 감소한 Secondary 구간 그리고 연속타점 후반 급격한 성장속도가 나타나는 Tertiary 구간으로 나누어진다. 일반 적으로 Primary 구간은 총 전극 성장크기의 약 $50 \%$ 수준에 서 나타나고 연속타점 수명의 한계는 Secondary 구간에서
발생하는 것으로 알려져 있다. ${ }^{8)}$ 본 실험에서는 연속타점 수 명 한계인 저항 점용접부 버튼 사이즈가 $4.5 \sqrt{\mathrm{t}}$ 이하가 될 때 연속타점을 종료하여 Primary 구간과 Secondary 구간 만 관찰되었다.

그림 4 (a)에 TRIP강판의 전극 선단경 측정 결과를 나타 내었다. TRIP강판의 경우 약 700타점까지 Primary 구간으 로 관찰되었으며 이후 Secondary 구간의 완만한 전극 성장 이 관찰되었다. 이러한 연속타점 수에 따른 전극 선단경의 변화는 버튼 직경 사이즈 변화와 비교하였을 때 동일 한 경 향이 나타난다. 그림 3 (a)의 저항 점용접 연속타점 수에 따른 버튼 직경 사이즈 변화에서 1200 타점 이전까지 약 6.5 $\mathrm{kN}$ 에서 $6.0 \mathrm{kN}$ 으로 버튼 직경이 감소하다가 이 후 2500타 까지 약 $5.70 \mathrm{~mm}$ 전후의 일정한 버튼 직경이 관찰된다. 1200 타점까지인 Primary 구간에서 전극의 성장이 빠르게 진행되었기 때문에 버튼 직경 사이즈의 감소 또한 빠르게 진행되었으며, 이 후 2500타점까지 완만한 전극 선단경의 성장을 보이는 Secondary 구간에서 버튼 직경 변화가 일정 한 것을 관찰할 수 있다.

그림 4 (b)는 $\mathrm{HPF}$ 강판의 저항 점용접 연속타점 시 전극
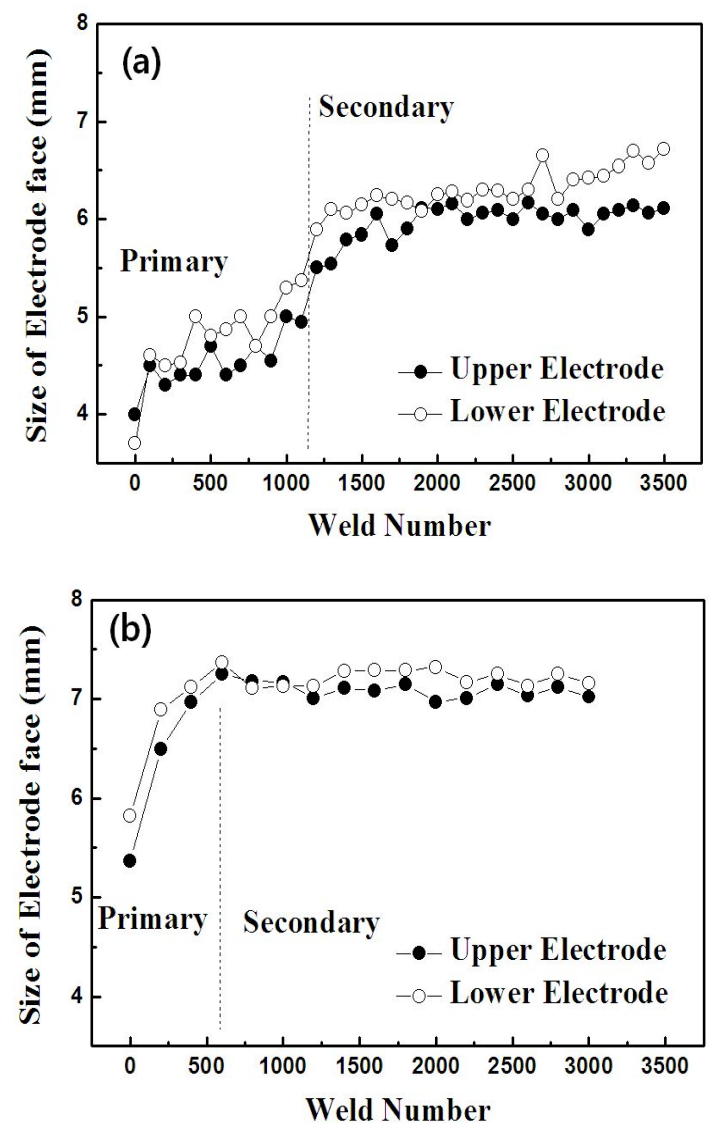

Fig. 4. Changes in face diameter of the electrode tip which were welded with (a) Zn coated TRIP Steel (b) Al coated HPF Steel. 
선단경의 성장을 나타낸 그래프이다. 전극 선단경 측정 결과 초반 500 타점까지의 급격한 성장 이후에 3000 타점까지 일 정한 전극 직경을 가진다. 그림 3 (b)의 저항 점용접 연속타 점 수에 따른 너깃 사이즈 변화에서 나타난 일정한 너깃 사 이즈 결과와 그림 4 (b) 의 전극 선단경의 변화를 비교해 볼 때, $\mathrm{HPF}$ 강판은 3000 타점 이상까지의 저항 점용접 연속 타점 시 일정한 전류 밀도를 가진 것으로 판단된다. $\mathrm{HPF}$ 강 의 저항 점용접 연속타점 수명평가에서 전극 선단경의 변화 가 없는 이유를 고찰하기 위하여 다음 장에서 전극 단면 합 금화 현상을 분석하였다.

\section{4 저항 점용접 연속타점 시 TRIP 강판과HPF 강판의 전극 분석}

연속적인 저항 점용접시 전극과 모재 사이의 최대 발열 온도는 약 $600{ }^{\circ} \mathrm{C}$ 전 후이며 이러한 전극의 높은 발열량은 모재의 도금층 $(\mathrm{Al}$ or $\mathrm{Zn})$ 성분과 전극 $(\mathrm{Cu})$ 의 합금화를 심 화 시킨다. 일반적인 냉연강판의 경우 도금층이 존재하지 않기 때문에 전극의 수명 또한 도금강판의 연속타점 수명보 다 길다. ${ }^{2(5), 8) ~ 10)}$ 저항 점용접 연속타점 시 도금층의 존재 는 전극 합금화를 심화시키는 요소이며 연속타점 수명을 결 정하는 결정적인 요소가 될 수 있다.
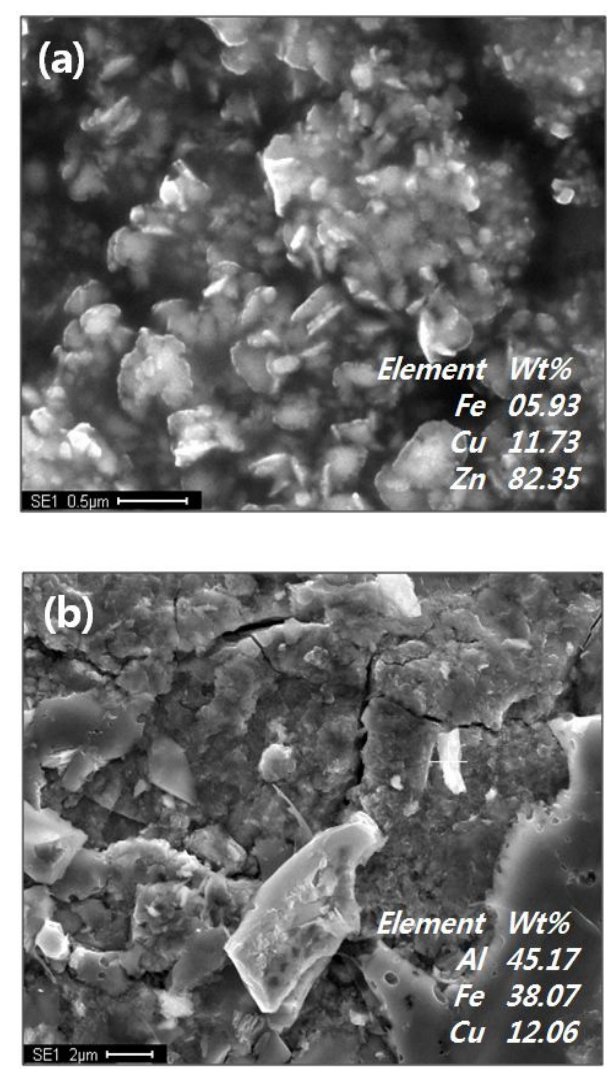

Fig. 5. SEM images of electrode after 3500 welds carried out with (a) Zn coated TRIP Steel (b) Al coated HPF Steel.
본 연구에서 사용된 TRIP강판과 $\mathrm{HPF}$ 강판은 각각 $\mathrm{Zn}$ 와 $\mathrm{Al}$ 도금에 적용된 강판으로 저항 점용접 연속타점 시 전극의 합금화 경향 또한 다른 형태로 진행되며, 이러한 $\mathrm{Zn}$ 와 $\mathrm{Al}$ 도금의 저항 점용접 연속타점 시 전극의 합금화 차이를 비교 분석하기 위하여 연속타점 종료 후 전극의 표면 및 단면을 $\mathrm{SEM}$ 과 $\mathrm{EDS}$ 로 분석하였다.

그림 5 는 TRIP 강판과 $\mathrm{HPF}$ 강판의 연속타점 후 용접에 사용된 전극의 표면을 $\mathrm{EDS}$ 를 통하여 분석한 결과이다. TRIP 강판에서 연속타점을 실시한 전극의 경우 아연 도금 층에 영향으로 전극과 도금층의 $\mathrm{Zn}$ 이 합금화가 발생하여, 연속타점 종료 후 전극표면의 $\mathrm{Zn}$ 함량이 $82 \mathrm{Wt} \%$ 이상 검출 되며 약 $11 \mathrm{Wt} \%$ 의 $\mathrm{Cu}$ 그리고 약 $5 \mathrm{Wt} \% \mathrm{Fe}$ 가 검출 되었다. $\mathrm{HPF}$ 강판의 연속타점 실시 전극의 경우 알루미늄 도금층의 영향으로 인해 전극과 도금층의 $\mathrm{Al}$ 에 합금화가 발생하여 전 극 표면에서 약 $45 \mathrm{Wt} \%$ 의 $\mathrm{Al}$ 이 검출되었으며 약 $12 \mathrm{Wt} \%$ 의 $\mathrm{Cu}$ 그리고 약 $38 \mathrm{Wt} \%$ 의 $\mathrm{Fe}$ 가 검출되었다. 전극의 표면 에서 도금층에 따라 전극의 합금화가 진행되는 것은 두 강판 이 동일한 것으로 판단된다.

그림 6 은 저항 점용접 연속타점 후 상부 전극의 단면을
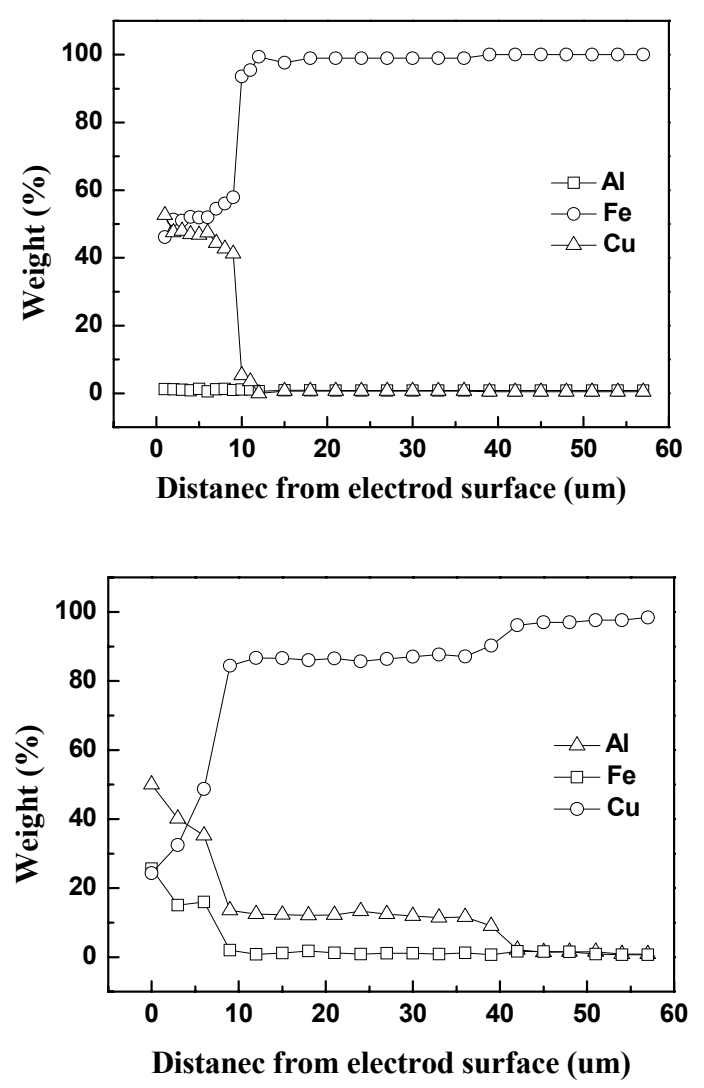

Fig. 6. Alloying layer analysis from the electrode tip through the thickness direction for electrode being welded with (a) $\mathrm{Zn}$ coated TRIP Steel (b) Al coated HPF Steel of electrode tip after electrode life test. 
절단해 $\mathrm{EDS}$ 로 전극 합금화 깊이를 분석한 결과이다. 전극의 단면을 분석하면 모재의 도금성분 $(\mathrm{Cu}$ or $\mathrm{Al})$ 과 $\mathrm{Fe}$ 성분이 전극 내부로 확산 된 전극의 합금화 깊이를 파악 할 수 있으 며, 전극의 최외각층은 분석 시편 제작 과정에서 일부 소실 되게 된다. 그림 6 (a)는 TRIP 강판의 저항 점용접 연속타 점 후 전극 단면의 합금화 분석 결과이다. 표면에서부터 약 $10 \mu \mathrm{m}$ 까지 도금성분 $(\mathrm{Zn})$ 이 검출되었다. 그림 6 (b)는 $\mathrm{HPF}$ 강판의 저항 점용접 연속타점 후 전극 단면의 합금화 깊이 분석 결과이다. $\mathrm{HPF}$ 강판의 경우에서도 약 $10 \mu \mathrm{m}$ 까 지 모재의 도금 성분 $(\mathrm{Al})$ 과 $\mathrm{Fe}$ 가 검출되었다. 전극표면 분 석 결과와 전극 단면 분석결과를 비교 해볼 때 두 전극의 합금화 깊이는 유사한 것으로 판단되나 전극표면에 발견되 는 도금성분의 양이 TRIP 강판의 경우 더 높게 측정되었다. 이러한 결과로 TRIP 강판에서는 전극 표면에 다량(약 82 $\mathrm{wt} \%$ ) 검출되는 $\mathrm{Zn}$ 의 영향으로 전극표면의 합금화가 심화 되어 전극 수명 평가에서 3200 타점의 전극 수명을 가지는 것으로 사료되며, $\mathrm{HPF}$ 강판의 경우는 전극 표면에 검출된 $\mathrm{Fe}$ 와 $\mathrm{Al}$ 의 영향으로 전극 선단경의 변화가 일정하게 유지 되어 연속타점 수명 측면에서 TRIP 강판보다 유리한 것으 로 사료된다.

\subsection{TRIP 강판과 HPF 강판의 전극 합금화 분석}

전기아연도금 된 TRIP강판의 경우 전기 도금법을 사용 한 도금강판으로 도금층의 표면이 평활하고 도금층이 일정 하며 약 $10 \mu \mathrm{m}$ 의 앏은 $\mathrm{Zn}$ 도금층이 관찰되는 강판이다. 그리고 일반적인 $\mathrm{Al}-\mathrm{Si}$ 도금을 사용하는 $\mathrm{HPF}$ 강판의 도금 층의 경우, Hot Press Forming 공정에서 모재의 $\mathrm{Fe}$ 와 도금 층인 $\mathrm{Al}-\mathrm{Si}$ 가 반응하여 도금성분은 기지방향으로 반응하 고, $\mathrm{Fe}$ 는 도금층 방향으로 반응해 도금층의 두께가 대략 35 $\mu \mathrm{m}$ 이상으로 나타나며 $\mathrm{Al}-\mathrm{Si}$ 과 $\mathrm{Fe}$ 그리고 표면 산화층 $\left(\mathrm{Al}_{2} \mathrm{O}_{3}\right)$ 으로 인해 4 가지 영역으로 도금층이 존재한다. ${ }^{6}$ 7) 저항 점용접 연속타점 실험에서 두 강판의 차이를 비교 했을 때, TRIP 경우에선 $\mathrm{HPF}$ 강판보다 비교적 결합력이 낮고 얇 은 $\mathrm{Zn}$ 도금층의 영향으로 연속적인 저항 점용접 시 전극 표면에서 반응이 일어나 전극의 축척과 이탈이 심화되며 그 림 4(a) 와 같이 전극 선단경이 증가하는 것이 관찰되었다. $\mathrm{HPF}$ 강판의 경우에서는 열간 압연으로 인하여 모재와 반응 이 일어나 비교적 결합력이 강하고 두꺼운 도금층과 표면의 산화층 $\left(\mathrm{Al}_{2} \mathrm{O}_{3}\right)$ 의 존재로 전극과의 합금화 현상이 억제되어 연속적인 저항 점용접시 전극 선단경의 변화에서 약 3000 타점까지 일정한 전류밀도가 관찰되었다. 이러한 실험 결과 는 전기아연 도금 강판의 $\mathrm{Zn}$ 도금층이 $\mathrm{HPF}$ 강판의 $\mathrm{Al}-\mathrm{Si}$ 도금층보다 연속적인 저항 점용접 측면에서 취약한 것으로 판단된다.

\section{4. 결 론}

전기아연도금 된TRIP 강판의 경우 $\mathrm{Zn}$ 이 내부로 합금화 되지 않고 전극 표면에 다량(약 $82 \mathrm{Wt} \%$ ) 검출되었다. 저항 점용접 연속타점 수명평가 시 전극은 연속적인 충격 (가압 력)을 받게 되며, 전극 표면에 주로 검출된 $\mathrm{Zn}$ 은 연속적인 충격으로 인한 전극의 마모을 심화 시킨 것으로 사료된다. 이러한 전극의 마모는 전극의 선단경 길이를 증가시키고 전 류 밀도를 변화시켜 버튼 직경이 감소하게 하였으며, 약 3200 타점의 저항 점용접 연속타점 전극 수명을 가지게 하 였다. 그러나 $\mathrm{HPF}$ 강판의 경우는 $\mathrm{Al}$ 도금층의 영향으로 인 해 전극 선단경 상승이 억제되었다. 전극 합금화의 깊이는 TRIP 강판과 유사한 결과가 관찰되었으며, 전극 표면에는 일정량 $($ 약 $45 \mathrm{Wt} \%)$ 의 $\mathrm{Al}$ 이 검출되었다. 도금층의 합금화 특성으로 인하여 연속적인 저항 점용접 시 전극의 선단경이 500 타점 이후부터 안정화되어 전류 밀도의 변화가 없었고, 너깃 직경이 3000타점 까지 일정하게 유지되었다.

1) Peel test를 이용한 전기아연도금 된TRIP 강판의 저 항 점용접 연속타점 실험에서 TRIP 강판은 3000 타점 전 후의 전극 수명이 나타냈으며, 연속타점 별 너깃 사이즈 측 정을 이용한 $\mathrm{Al}-\mathrm{Si}$ 도금 $\mathrm{HPF}$ 강판의 저항 점용접 연속타점 실험에서는 3000 타점 이상까지 약 $7.3 \mathrm{~mm}$ 전후의 일정한 너깃 사이즈가 관찰 되었다.

2) $\mathrm{Al}-\mathrm{Si}$ 도금 $\mathrm{HPF}$ 강판은 전극 선단경의 변화에서도 일정한 전극 직경을 가지며 3000 타점 이상 까지 일정한 전류밀도를 가지는 것으로 사료된다.

3) $\mathrm{EDS}$ 를 이용한 전극 합금화를 분석한 결과 전기아연도 금 된 TRIP 강판이 $\mathrm{Al}-\mathrm{Si}$ 도금 $\mathrm{HPF}$ 강판보다 전극 합금화 에 취약한 것으로 판단된다.

\section{참 고 문 헌}

1. T. H. Kim, Ph. D. Thesis, p. 1, Hanyang University, Seoul (2006).

2. J. Zou, Q. Zhao, and Z. Chen, J. Mater Proc Tech. 209, 4141 (2009).

3. S. S. Park, MS. Thesis, p. 34, Dong-Eui University, Busan (2009).

4. S. S. Park, S. M. Lee, Y. J. Cho, N. H. Kang, J. H. Yu, Y. S. Kim, and Y. D. Park, J. Kor. Inst. Met. \& Mater., 46, 672 (2008).

5. S. S. Park, Y. M. Choi, D. G. Nam, Y. S. Kim, J. H. Yu, and Y. D. Park, J. KWJS., 26, 625 (2008).

6. B. K. Choi, H. S Son, and H. G. Kim, KSAE, 11, 1-3271 (2009).

7. Y. G. An, C. Y. Kang, Y. S. Kim, C. H. Kim, and T. K. Han, J. KWJS., 29, 1-134 (2011)

8. N. T. Williams and J. D. Parker, Int. Mater. Rev., 49, 2 (2004). 
9. Kevin Randall Chan, Ph. D. Thesis, p. 61, Waterloo University, Ontario (2005).

10. K. H. Kim, Y. M. Choi, Y. S. Kim, Y. M. Rhym, J. H. Yu, N. H. Kang, and Y. D. Park, J. KWJS, 26, 511 (2008).
11. J. B. Kim and S. K. Lee, J. Corros Sci. Soc. of Kor., 30, 5 (2001).

12. N. Fujita, K. Matsumura, T. Nonaka, T. Tomokiyo, Corros. Sci. Tech., 9, 16 (2010). 